\title{
Aspectos do romance São Bernardo
}

\section{Atilio Bergamini Junior ${ }^{*}$}

\begin{abstract}
Resumo: Este ensaio argumenta que o tema da reificação em São Bernardo, de Graciliano Ramos, está tanto mais presente no romance quanto mais reificada for a posição de leitura.
\end{abstract}

Plavras-chave: Graciliano Ramos; reificação; leitura

\begin{abstract}
This essay argues that the theme of reification in Graciliano Ramos' novel São Bernardo is part of the book, but also, that this theme becomes more present the more reified the reader's position is.
\end{abstract}

Keywords: Graciliano Ramos; reification; reading

Acompanhemos as últimas linhas de São Bernardo, publicado por Graciliano Ramos em 1934. O objetivo será atar as duas pontas do livro por meio de uma comparação de seus traços mais evidentes. Depois, teremos instrumentos para generalizar uma postura que nos guiará até o final deste artigo: "E eu vou ficar aqui, às escuras, até não sei que hora, até que, morto de fadiga, encoste a cabeça à mesa e descanse uns minutos” (RAMOS, 1995, p.191). Trata-se de um parágrafo composto por uma só frase. O motivo principal é um homem, à mesa. A locução "vou ficar" prevê o futuro imediato. Pode aparecer ao leitor a imagem de um vulto betumoso, encurvado sobre uma mesa, escrevendo, não sem certo esforço, numa sala vazia.

Sigamos agora as primeiras linhas de São Bernardo: "Antes de começar este livro, imaginei construí-lo pela divisão do trabalho" (Idem, p.5). Como o final, a passagem se constitui de uma frase que ocupa um parágrafo curto. Mas aqui, não há interpolações.

Cada uma das duas frases citadas acima é metonímia - aqui está a generalização - do movimento geral do livro, que parte da certeza do narrador para a incerteza (mas, e isso é fundamental, um narrador que parte da incerteza para narrar a certeza do início), da reificação de si e do mundo para uma problematização incoerente. Nas duas frases, há um projeto. Na última, lê-se um desejo de descanso, ainda que mínimo, para os conflitos e perturbações do narrador. Na primeira, um projeto que se anuncia frustrado. "Imaginei construí-lo" - diz o narrador sobre o livro que, mais tarde o leitor saberá, não construiu como esperava. A

\footnotetext{
* Mestrando em literatura brasileira na Universidade Federal do Rio Grande do Sul. Trabalho originalmente produzido a partir das discussões em aulas da professora Dra. Regina Zilberman a quem cabem os créditos de orientação. Bolsista CAPES.
} 
impossibilidade de planejamento, o dar com os burros na água e a carência de instrumentos afetivos e intelectuais serão temas de todo o livro, que acusa, nessa toada, a literatura como modo de extorquir a expressão, mas, ao mesmo tempo, como modo possível de expressão lúcida. Mais adiante explicarei melhor essa idéia. Por agora é preciso dizer que o Paulo Honório posto em cena em São Bernardo, a princípio, não poderia escrever literatura. Ele, aliás, sugere o tempo todo que não faz literatura.

As pessoas que me lerem terão, pois, a bondade de traduzir isto em linguagem literária, se
quiserem. Se não quiserem, pouco se perde. Não pretendo bancar o escritor. É tarde para mudar
de profissão. E o pequeno que ali está chorando necessita quem o encaminhe e lhe ensine as
regras de bem viver. (RAMOS, 1995, p.9-10)

Ao construir uma personagem que não lê nem escreve literatura, Graciliano Ramos caracteriza um problema importante para a literatura em sentido largo e que, no caso brasileiro, tem ocupado críticos por diversas gerações, chegando aos nossos dias nas posições, sob esse aspecto, divergentes de Roberto Schwarz e Silviano Santiago. Vale a pena acompanhá-las.

Schwarz (1988 e 2000) aponta para o que chama de inautenticidade das formas culturais e intelectuais importadas pelas elites e utilizadas "fora de lugar". A forma das produções culturais caracterizaria, assim, o lugar do Brasil no sistema capitalista global: uma periferia dependente, mas ainda assim plataforma de alto rendimento para a crítica do conhecimento e da economia ocidental (como no caso Machado de Assis).

De outra maneira, Silviano Santiago (1978) entende que há eurocentrismo e neocolonialismo no posicionamento de críticos como Schwarz - e Schwarz volta a Silviano lendo suas conclusões, a par, diz ele, da validade dos argumentos, como abstração teórica sem raiz nos processos objetivos. Para Santiago, a antropofagia aliada à transgressão de valores tradicionais permitiria que o silenciamento das minorias se transformasse em escritura e que a repetição da forma tivesse rendimento estético crítico (cf. CARDOSO, s/d e TELLES, 2004).

Literatura que nega a si mesma? Literatura que se propõe outra em relação aos pendores parnasianos? As duas coisas?

A autonomia do livro - frente aos empenhos elitistas nacionalistas (mais presentes do que nunca na década de 1930, reforçados então pela legitimação do modernismo), bem como frente a alguma pretensa herança universal (com aproveitamento recriador da literatura européia ou norte-americana) - faria supor qualquer coisa de ilegível, na fronteira mais irreconhecível da inovação; mas nesse ponto Graciliano soube entrever um não-leitor. 
Que um livro não seja literatura, isso pode ser um problema num lugar em que se lê literatura e os protocolos de leitura estejam firmemente acordados. Onde pouco se lê literatura, o leitor implícito pode ser um não-leitor, sem que isso sirva para rebaixá-lo, antes o contrário.

Marisa Lajolo e Regina Zilberman estudam, na primeira parte de A formação da leitura no Brasil, relações entre leitores ficcionais e narradores. As autoras chamam - tendo como exemplos Quincas Borba e Memórias póstumas de Brás Cubas, mas também, embora de outra maneira, Amar verbo intransitivo - de "diálogo de um só" aquele em que o narrador rebaixa ou desconsidera o leitor: "enquanto o narrador conquistou [ao longo da constituição da leitura no Brasil] mais autoridade, o leitor continua sendo julgado incapaz para andar por suas próprias pernas" (LAJOLO \& ZILBERMAN, 1996, p.39).

As pesquisadoras argumentam que a "maturidade do leitor", na constituição da leitura no Brasil, quem a constrói ficcionalmente é Graciliano Ramos. Nos primeiros capítulos de São Bernardo, dizem elas, o autor "muda o patamar ocupado pelo leitor na metalinguagem da ficção brasileira" (Idem, p.45).

Não vinga a divisão de trabalho proposta pelo narrador na primeira frase do livro; ele demite os funcionários da empreitada e restam, na divisão do trabalho, apenas o leitor e o narrador. "Como ele [Paulo Honório] carece de um ouvinte, a aproximação entre ambos [Paulo Honório e leitor] jamais se exerce na tradição autoritária de um narrador que se julga superior a seu leitor" (Idem, p.47). Quando o leitor e o narrador se constituem na forma do livro como despossuídos de literatura, não se trata aí de uma forma de regressão estética, antes o contrário. O fato de a ambos a literatura estar interditada comporá - caso minha leitura se sustente - um dos alvos críticos do livro, sem que, contudo, a literatura - ao menos nos termos em que era entendida - fosse um ideal a ser alcançado no fim do processo.

A seguirmos a opção de Zilberman e Lajolo, a relação entre "eu” e "tu”, "narrador" e "leitor" - ao longo de sucessivas gerações de escritores (brasileiros, ao menos) - aparece desnivelada pela literatura, com distinção valorativa para o narrador. Mas em São Bernardo se passa algo diferente. (Fingir) não ser literatura é um dos complexos jogos estéticos do romance. A problemática esteve exposta em Memórias póstumas de Brás Cubas, desde a passagem em que o narrador paga seu leitor com um piparote, depois de prever que - com aquele tipo de livro - não agradaria nem aos graves, nem aos frívolos (como se só existissem leitores graves ou frívolos e nada mais). Paulo Honório, diferentemente de Brás Cubas, se aproxima dos leitores (não-leitores, na verdade) e se afasta das personagens do livro. Nisso, o leitor é levado a duvidar da identificação com o narrador; identificação que não será negada 
de todo, nem realizada de pleno. Ambos, leitor e narrador, não possuem literatura. Ambos, leitor e narrador, têm motivos para entender a literatura como um sutil instrumento de reprodução de divisões e desigualdades em uma sociedade absurdamente dividida e desigual.

Nesse recorte, acontece como que uma reificação de São Bernardo por muitos de seus leitores, que acabam, salvo melhor juízo, exigindo que narrador, leitor e narração coincidam com conceituações prontas, eivadas de senso comum e preconceito de classe, bem como de aprofundamentos teóricos válidos para outros momentos e leituras, mas inválidos e mal argumentados diante do livro de Graciliano. Não é rara a acusação - como se fossem determinados leitores os fundamentos suficientes da verossimilhança - que Paulo Honório não pode ser alguém que escreve. Ou seja: o leitor refunda preconceitos e divisões sociais e cobra que eles sejam verdade, mesmo quando são mentira.

Essa reificação externa à lógica da obra terá outra reificação, bastante referida pela fortuna crítica do romance, com que lidar, a das relações que o narrador estabelece. Contudo, se vermos diretamente em Georg Lukács (1974), concluiremos que não se trata de encontrar a reificação em determinada pessoa ou em determinada coisa, o que seria reificar o próprio conceito, naturalizando ou essencializando as características de um objeto. Uma relação reificada, diria Lukács, é aquela em que a subjetividade se torna objeto e em que a objetividade se apresenta como evidência última, sem subjetividade, sem qualidade, sem mediação.

Paulo Honório não cresceu numa sociedade industrial, que, a julgar a partir de Lukács - e salvo melhor leitura -, seria a condição objetiva da reificação. No passo em que, ficcionalmente, o narrador escreve, ocorre, no Brasil, o início da industrialização financiada pelo capital estrangeiro e por uma "oligarquia anti-burguesa" (OLIVEIRA, 1977). As condições objetivas de produção de relações eram extremamente diversas daquelas a partir das quais tanto Marx quanto Lukács teorizaram os conceitos irmãos de fetiche da mercadoria e reificação, respectivamente. Com Francisco de Oliveira (1977), pode-se perceber que, no final da República Velha, a exportação de café produz riqueza, mas não produz capital ${ }^{1}$.

Pergunto-me, com isso, se a reificação de Paulo Honório, em alguma medida, não repercutiria a reificação da leitura e da interpretação, mais especificadamente, da leitura e da

\footnotetext{
${ }^{1}$ Trata-se de uma questão controversa. Entretanto, estudos recentes como os de Manolo Florentino e João Luís Fragoso levam a crer que o mercantilismo instalado no Brasil desde o século XVI até o século XIX se constituiu por meio de um sofisticado sistema de trocas em que o dinheiro líquido era quase um monopólio de pouquíssimas famílias e da própria Coroa portuguesa. Assim, açúcar e escravos, por exemplo, funcionavam como moeda. Nesse caso, a colônia brasileira foi dos lugares mais capitalizados do planeta sem a necessidade de liquidez de capitais. Acrescenta a isso a idéia formulada por Fernando Henrique Cardoso: a de que quando os escravistas diziam que havia "falta de braço", deve-se ler aí: "falta de capital".
} 
interpretação nas últimas décadas, quando surgiram as condições objetivas para que o leitor exigisse do narrador que tivesse certa posição de classe que o permitisse ser narrador. É como se se exigisse que as "propriedades e faculdades da consciência" de Paulo Honório correspondam a um conceito pronto e, como eu disse, talvez reificado, de literatura; conceito em que narrador, leitor, enredo e personagens possuem papéis imediatamente reconhecíveis e exigíveis - mesmo num país de não-leitores -, na falta dos quais se pode reivindicar o direito de criticá-los "legitimamente". Seguindo tal interpretação, como leitores, perderíamos a possibilidade de enxergar as diversas modificações das personagens, que dificultam, se não impedem, compartimentalizações teóricas, e poríamos a perder as modificações na concepção de leitura e literatura ao longo da história brasileira, concepções que São Bernardo problematiza em alto grau (cf. LAJOLO \& ZILBERMAN, 1996).

À exemplo das “modernizações” do Brasil, a modernização da fazenda São Bernardo, à qual Paulo Honório dedicou sua vida, resultou num elefante branco. Máquinas (importadas) que não chegam; empréstimos que não saem (porque são de altíssimo risco, numa sociedade assim desprovida de liquidez); estradas que não servem para nada; mercados incipientes capitalizados a custo de concentração de renda pelo próprio governo nacional e pelos políticos locais; móveis e utensílios em completo descompasso com as necessidades das pessoas e do lugar; submissão à volubilidade do mercado externo entre-guerras.

Sem possibilidade de decidir sobre si, enredada internamente nas relações estamentais e externamente nas relações capitalistas, a "revolução burguesa no Brasil” procurou se adaptar ao mercado internacional ${ }^{2}$.

Com isso, repetiu-se o que as mais antigas aristocracias patriarcais já tinham feito, interditando a possibilidade de uma discussão de projeto nacional que incluísse os trabalhadores urbanos e rurais, muitos dos quais vivendo ainda em regime semi-escravo (FRAGOSO \& FLORENTINO, 2005).

Paulo Honório "vê" a fazenda crescer e se estabelece como capitalista ao mesmo tempo que finca pé no patriarcalismo - não há, em verdade, condições objetivas para implantar capitalismo de acumulação no Brasil. É um dos temas do romance.

A princípio, diz ele, o capital se desviava de mim, e persegui-o sem descanso, viajando pelo sertão, negociando com redes, gado, imagens, rosários, miudezas, ganhando aqui, perdendo ali, marchando no fiado, assinando letras, realizando operações embrulhadíssimas. (RAMOS, 1995, p.12)

\footnotetext{
2 Às vezes temos a impressão de que se trata de uma particularidade do Brasil. Mas valeria um estudo de Antonio Gramsci, por exemplo, que, a propósito (1978) percebia o mesmo processo nos caminhos da Itália pósunificação.
} 
Sem possibilidade de acumular, Paulo Honório recorre ao roubo e a empréstimos. Se fosse um fazendeiro real, possivelmente pagaria em juros a quantia que, de outro modo, possibilitaria a acumulação - gerando acumulação de liquidez nas mãos de poucos, mas promovendo uma permanência, ainda, dos signos aristocráticos (casarões, mão-de-obra barata, monocultura, jóias). A dificuldade por parte dos agentes econômicos de reconhecer os novos processos em que se metiam - processos que demandavam urgentemente o fim da política agro-exportadora (por ser inviável) e ao mesmo tempo impossibilitavam a produção de um mercado interno já que a liquidez monetária era quase um monopólio - é, a meu ver, um dos temas da primeira parte do livro:

Quando se acabariam aqueles serviços moles? Desgraçadamente faltavam-me recursos para atacá-los firme. Assim, mesmo lidando com pessoal escasso, às vezes na sexta-feira eu não sabia onde buscar dinheiro para pagar as folhas do sábado. (RAMOS, 1995, p.54)

Desse modo, "as coisas" acontecem à revelia do sujeito - que, a pensar bem, se constitui por meio de auto-negações e incompletudes: não-escritor, não-leitor, não-aindacapitalista. Escreve Paulo Honório:

A verdade é que, aparentando segurança, eu andava assustado com os credores. Ia bem, sem dúvida, o ativo era superior ao passivo, mas, se aqueles malvados quisessem, capavam-me. Agora os receios diminuíam. A escola seria um capital. Os alicerces da igreja também eram capital. (Idem, p.43)

Nesse compasso, nem dias santos e feriados ficam a salvo do tabu do lucro do proprietário (e do tabu do lucro do capital inglês e norte-americano). O ritmo secular do calendário litúrgico perde espaço - sem enfrentamentos legais.

Aqui, nos dias santos, surgem viagens, doenças e outros pretextos para o trabalhador gazear. O domingo é perdido, o sábado também se perde por causa da feira, a semana tem apenas cinco dias, que a Igreja ainda reduz. O resultado é a paga encolher e essa cambada viver com a barriga tinindo. (idem, p.54)

Vê-se de onde saem o lucro do proprietário rural e a conseqüente acumulação do capitalismo inglês e norte-americano: de pessoas que, trabalhando "cinco dias por semana", não recebem nem mesmo o suficiente para não ficar com a barriga tinindo. Acrescente-se que, dos dias livres, muitos deles, no Brasil real, são utilizados no cultivo de uma pequena roça de subsistência, na pesca e na criação de pequenos rebanhos.

Tudo isso se passa no nível objetivo. No nível subjetivo - em que pese a grosseria da divisão -, as coisas não vão de um modo muito diferente:

Amanheci um dia pensando em casar. Foi uma idéia que me veio sem que nenhum rabo-desaia a provocasse. Não me ocupo com amores, devem ter notado, e sempre me pareceu que mulher é bicho esquisito, difícil de governar. (Idem, p.57) 
A falta de instrumentos para se aproximar das mulheres, bem como a falta de instrumentos para escrever literatura, se ligam à impossibilidade de se constituir como capitalista. Não mais coronel, Paulo Honório precisará encontrar outros pontos em que constituir e respaldar seu poder e os sentidos de suas ações. A via apresentada por Madalena se mostrará impossível, mesmo para um homem que trabalhou na sapa, por uma miséria. A ascensão financeira levou-o a distinguir-se do passado, e a miséria que o constituiu não lhe diz respeito. Os livros que provocaram a alienação deste Dom Quixote calculam a contabilidade da fazenda.

Se tomarmos propriedade no sentido recorrente em língua portuguesa de qualidade ou característica, fica claro que as possessões de Paulo Honório não se tornam propriedades suas, com a exceção, talvez, da velha Margarida. São Bernardo, Madalena, a pomicultura, o herdeiro: sob os índices da ética protestante, as "propriedades" se tornariam imediatamente qualidade de quem as possui (por merecimento e benção), mas, nas condições de Paulo Honório, as propriedades (nos dois sentidos) se distanciam de seu passado. São propriedades somente na medida em que geram lucro, antigo tabu das decisões políticas no liberalismo escravista brasileiro.

Tanto a fazenda quanto a mulher parecerão, desde sempre, alienadas ao destino de Paulo Honório, ou porque Madalena não se deixará governar ou porque a fazenda se inserirá em uma economia industrial controlada por decisões econômicas alhures - escola e igreja, tudo será capital. Florestan Fernandes (1986, p.149) chama de "modernização dependente" a que ocorre nos anos 1930, quando Paulo Honório, supostamente, escreve seu testemunho. Vêse daí que o patriarcalismo, o machismo, o preconceito e a arrogância de Paulo Honório são características constitutivas da "modernização" capitalista.

Em termos literários, existiria uma expressão para a subjetividade alijada de seu sentido: é o distanciamento, a falta de relação imediata entre os temas tratados em São Bernardo e a forma da escrita de Paulo Honório, ao menos na primeira metade do romance. Duas ressalvas, porém: (1) não se constrói teoricamente o distanciamento literário como reflexo do distanciamento econômico, senão a partir de diversas mediações, quais sejam, a própria forma literária, e um complexo sócio-político-cultural abrangente que dá ressonância particular ao dispositivo econômico. (2) Dizer que há uma forma que corresponde a determinados temas ou conteúdos e vice-versa não deixa de ser limitador e perigoso, na medida em que pode automatizar sentidos, vindo a naturalizá-los.

Cumpre dizer que nem Paulo Honório, nem Madalena, nem a fazenda, nem a sociedade tornada escrita, nada no livro é o mesmo do início ao fim, nem mesmo sua forma, 
que, como vimos no início deste texto, se altera até mesmo no nível sintático. Em todos e em tudo ocorrem mudanças, ora lentas, ora repentinas. E, no entanto, um dos efeitos da literatura de Graciliano, de um modo geral, é a imobilidade. As mudanças agem em prol da imobilidade; a imobilidade política gera uma sucessão de novas leis, relações e valores - em prol de si mesma -, gera, enfim, um astuto movimento social. A frase enxuta - construída a partir do olhar distante e do julgamento pragmático - expressa por condensação o barroquismo da justificativa do lucro, tabu imediato e livre de contestação institucional, a estruturar o sujeito Paulo Honório (e, em seguida, desestruturá-lo).

Mas espera lá, dirá o leitor mais atento: você diz e desdiz? O lucro estrutura ou desestrutura Paulo Honório? Como assim? As duas coisas. Não há descanso nessa dialética. Imóvel e distanciado, ao longo de todo o livro, dificilmente o narrador se aproxima de alguém ou alguma coisa. Mesmo Madalena nunca passa de uma idealização. Quando ela se impõe como palavra e corpo, Paulo Honório procura refazer seu ideal - que não é dele, claro esteja, mas de uma estrutura patriarcal que o precede - com violência e irritação.

Assim, ao longo da narração, não há gostos, nem toques. Predominam os sentidos distantes, a audição e a visão. Não intuímos se as mãos de Margarida ainda trazem calos ou se a velhice as amaciou. O rosto de Madalena, não o conhecemos, nem sabemos qual é o aspecto táctil de seu cabelo, pele ou mãos. O bafo de Padilha? A utilidade dos móveis e utensílios comprados pela personagem? O cheiro da comida, do café, do cigarro enrolado? As bostas do rebanho? Nada. Da casa, não sabemos se têm tapetes, cortinas; não conhecemos os cheiros da cozinha, nem experimentamos o perfume "da mulher de Mariano". Paulo Honório enxerga apenas quantidades, representadas, até onde sou capaz de entender, pela mimese da visão e audição distanciadas. Personagem de tônus pragmático - o que faria supor materialidade - ele pensa de modo abstrato, isto é, financeiro.

Num artigo bastante citado, dedicado ao conceito de reificação, Lucien Goldmann (1979, p.122) afirma: “a reificação [...] se estende progressivamente ao conjunto da vida psíquica dos homens, onde ela faz predominar o abstrato e o quantitativo sobre o concreto e o qualitativo". E já que me saí com uma empilhada de citações, lá vai mais uma, essa de Fredric Jameson (1985, p.146), num importante trabalho sobre a obra de Lukács: “o capitalismo é, ele próprio, a primeira coisa-em-si, a contradição primordial que fundamenta todos os outros dilemas mais particulares e mais abstratos".

De fato, São Bernardo mimetiza relações sociais em que o mais abstrato (o ganho financeiro) é tido como o mais concreto. A percepção da personagem se apresenta como concepção dura, objetiva, realista do mundo, visando a produção de riqueza. Nesse compasso, 
produzir riqueza é ser pragmático, ir direto ao ponto, enquanto produzir relações pessoais é metafísico, abstrato e perda de tempo. O mais físico se torna metafísico, o mais abstrato se torna concreto. A percepção de Paulo Honório não construirá aspectos de totalidade, porque o cálculo requer análise, isto é, separação alienada. A pedreira, a pomicultura, os rebanhos, os empregados, Madalena e São Bernardo, de um lado, e, de outro, os bancos, os importadores de maquinários e os governos não parecem fazer parte da mesma sociedade. A consciência da ligação objetiva entre os procedimentos políticos e a vida miúda se dá apenas - mas ainda de modo vacilante - com a falência e a revolução, ao final do livro, mas, dessa vez, e uma vez mais, Paulo Honório analisa a questão para encontrar responsabilidade na vida agreste naturalizando o ponto. De novo, uma abstração passa como realismo estrito.

Proponho, aqui, sovar um pouco o conceito de reificação. Começo lembrando o seguinte trecho de História e consciência de classe:

E não há, em conformidade com a natureza, qualquer forma de relação dos homens entre si, qualquer possibilidade para o homem de fazer valer as suas 'propriedades' físicas e psicológicas, que não esteja submetida a esta forma de objetividade [a reificação]. (LUKÁCS, 1974, p.115)

Salvo leitura equivocada, o conceito de reificação foi elaborado por Lukács a partir da teorização sobre o caráter fetichista da mercadoria de Marx, exposta no primeiro volume d' $O$ capital (MARX, 1984, p.79-93). Teorizando a alienação e divisão do trabalho como produtoras de realidade, Lukács se perguntou de que modo seria possível agir no mundo sem alienar-se ou dividir-se. Uma das respostas descreve a necessidade - dada certas condições históricas - de despir o véu da reificação e entender as relações sociais como relações históricas entre seres históricos. A reificação, assim um conceito filosófico e político, aparece como totalidade estrutural que, ao produzir alienação e divisão, não cessa de reproduzir a si mesma. O processo de abstrair o concreto e concretizar o abstrato, em outra medida, de ver como natural o histórico, é a maneira de Paulo Honório - e outros muitos personagens descrever as relações e o espaço em que se insere.

Para Lukács, os proletários tinham a "possibilidade" de "tirar o véu da reificação", uma vez que podiam compreender a própria posição frente à totalidade do ser social. Os proletários - Lukács acreditava quando escreveu História e consciência de classe - eram a um só tempo sujeitos e objetos da história, o que determinava subjetiva e objetivamente as condições para a revolução proletária do modo de produção. $\mathrm{O}$ burguês, preso nas armadilhas do "pensamento antinômico", teria seu limite intelectual no apocalipse da história para o qual ele dava legitimidade (LUKÁCS, 1974). 
A reificação, diria Lukács, é conseqüência e condição da divisão e do isolamento das partes em relação a si mesmas e em relação ao todo. Seria apreensível, portanto, em termos sociológicos e em termos psicológicos: ela não é um dado, nem é uma abstração, é relação concreta. Calcado nisso, Mikhail Bakhtin (2004) constrói sua crítica ao que ele chama de "freudismo": a separação, com efeitos de verdade, da subjetividade e da objetividade, do indivíduo e da sociedade. A reificação, desse modo, reproduz e é reproduzida - por meio das mais diversas instituições e posições-sujeito (medicina, direito, jornalismo, publicidade, escola) - por hierarquias, linearidades e causalidades que inscrevem naquilo que é particular da relação capitalista uma expressão de generalidade e inevitabilidade, barrando o agir do homem e o entendimento das conseqüências de seu trabalho. Segundo Casimiro, em São Bernardo: as coisas sempre tiveram dono, isso é assim.

No direito, no casamento, no jornalismo, nas crises, Lukács repara uma racionalização de cada parte visando o lucro. Alguns exemplos no romance: Paulo Honório expressa o desejo de a personagem Glória deixar de fazer tantas atividades para se concentrar numa coisa só (especialização); imagina mulheres em partes, mas não consegue pensar nenhuma como um todo (fetichização); começa a escrever um livro pela divisão do trabalho (racionalização e lucro - simbólico e financeiro); entende que Madalena deveria ficar em casa e não sair tanto para conversar com os funcionários da fazenda (divisão sexual do trabalho); admira o juiz, que prefere não opinar sobre literatura e política, pois é somente juiz e deve se limitar a julgar (divisão do trabalho intelectual, especialização).

Bakhtin (mas não só ele) via na subjetivação da vida, na compartimentação de cada indivíduo, um trabalho ideológico. Porém, Paulo Honório, ao subjetivar-se, inclusive como proprietário e aspirante a capitalista, constrói as estruturas que lhe possibilitam notar (mas não despir) "o véu da reificação" e compreender, sem a mediação pelo tabu do lucro, um pouco mais as relações entre os homens. Madalena não aceita ser a mulher que "deve ser" e, pela morte, inscreve sua presença e singularidade no modo endurecido e intransigente como Paulo Honório a percebe. Aliás, Madalena não diz o que sente a Paulo Honório, porque, ao ser violentamente não vista nem ouvida em sua singularidade, ela não pode ser alguém diante do marido. Madalena escreve uma carta, falando de sua tristeza e dos motivos para sua morte. A escritura como possibilidade de subjetivação é, portanto, uma encenação importante do livro, já que, além de Madalena, Paulo Honório passa a escrever.

O aprofundamento de Paulo Honório em sua subjetividade - quem sabe a própria construção da subjetividade ao encontrar um outro (no caso, a morte de Madalena) - tem, estamos às voltas com isso desde o primeiro parágrafo deste texto, lastro na forma do 
romance. João Luiz Lafetá (1995) descobriu, na segunda parte do livro (a partir do casamento de Paulo Honório e Madalena), a prevalência de cenas e gerúndios (onde antes havia sumários e orações coordenadas). Trata-se, então, de ir somente até aqui com os postulados de Lukács, porque, para ele, o conceito de reificação repercute a aplicação do materialismo dialético a uma leitura do "ponto de vista do proletariado" (em Marx principalmente) em contraposição às "antinomias do pensamento burguês" (em Kant principalmente). Não apenas no ensaio sobre a reificação e a consciência do proletário, mas também em "O que é o marxismo ortodoxo?" e "A consciência de classe" - todos reunidos em História e consciência de classe -, Lukács critica a objetividade, a leitura de dados, procurando mostrar que a generalização, a objetividade e os dados foram (re)produzidos pelo trabalho humano. Vê-los em senda de objetividade seria vê-los sem a mediação do trabalho, em outras palavras, da subjetividade de alguém, em determinada posição, agindo para determinados fins, nos limites de uma determinada sociedade. Inscrever na objetividade a subjetividade - mostrando na cisão entre as duas um sintoma da reificação - é uma das preocupações do livro de Lukács.

A reificação seria, numa construção propositalmente simples, efeito das relações em sociedades capitalistas. O "sintoma" estaria na cisão entre subjetividade e objetividade, e a conseqüência seria o empobrecimento do particular subsumido pela totalidade. Em outros termos, a "categoria universal do ser social total", a reificação, dissimula as relações entre homens como se fossem coisas dispostas entre coisas. A reificação, nesse sentido, não é algo empiricamente verificável, mas possibilita, como estrutura do pensamento, que a abstração financeira tenha um caráter de realidade inescapável. A exemplo do inconsciente freudiano, a reificação seria apreensível apenas em seus efeitos.

Paulo Honório nasceu em meio ao campesinato rural, talvez a camada social mais empobrecida do Brasil da época. Foi trabalhador avulso e solitário. Jamais foi proletário, no sentido que Lukács dá ao termo. Mas também não se tornou, mais tarde, o burguês da acumulação capitalista. Como compreender a complexidade subjetiva de uma personagem que passa por diversos estratos sócio-econômicos, sem contudo passar pelas categorias geralmente atribuídas às subjetividades européias? De que maneira específica ocorreria reificação numa tal condição?

Vimos que o conceito de reificação em Lukács é um conceito negativo. Coube a Adorno sugerir uma tomada, por assim dizer, positiva da reificação. Ao escrever um dos pontos basilares de sua Teoria Estética, ele diz que "a arte só permanece viva por intermédio de seus poderes essencialmente sociais de resistir à sociedade; a menos que ela se submeta à reificação, ela se torna mera mercadoria" (ADORNO, 1998, p.16). Adorno vê na construção 
reificada da expressão um modo de dialetizar em negativo a arte, o que agrega aspectos para nossa leitura do processo de distanciamento e objetificação na linguagem de São Bernardo.

Tanto num caso, como noutro, o problema da reificação é central, mas já ficou claro que seria abdicar de pensar a questão recolher um conceito pronto, aqui ou ali, para aplicá-lo no romance de Graciliano Ramos. Seria, em última instância, reificar o conceito de reificação, reproduzi-lo, enfim, sem produzi-lo efetivamente.

Fica evidente, não obstante, que a teoria da reificação, tal como a entendeu Lukács, interpreta a contento alguns dos conflitos do romance - e, de certa maneira, informa muitas das disposições da crítica que hora escrevo, na insistência proposital (mas nem por isso menos reificada) da divisão entre forma e conteúdo. Informa, inclusive, a narração da vida de Paulo Honório, que inicia somente no momento que este começa a fazer-se um homem de negócios. A quantidade se torna o que Marx chama de "qualidade objetiva do objeto", "qualidade inerente às coisas", tomando de assalto a subjetividade do narrador e sua linguagem. Aos poucos, a escrita revela a Paulo Honório a qualidade angustiante das relações sociais.

A partir da alienação, Paulo Honório constrói um saber a respeito de si e do mundo e se lança na compreensão de uma subjetividade reificada que, no absurdo da reificação, lhe registra as possibilidades de transformação (cf. ELIAS, 1990). Eis o limite até aonde podemos ir com Lukács ${ }^{3}$.

Na linguagem aparentemente cindida do conteúdo que expressa, o livro evidencia uma reificação de dupla camada: da linguagem com o conteúdo e do leitor com a verossimilhança. A reificação garante a cisão dual e incomunicável entre os pólos, mas ela não se conclui no livro, porque ele decanta uma poeira crítica indecidível. Se não está toda nas relações internas ao enredo, em que relações está a reificação? Eis que, as relações internas não são dados imediatamente reconhecíveis, mas sim, sempre, interpretações que, em certas condições, se tornam "dadas". Digamos que (1) as personagens lutassem contra a reificação; (2) Madalena transformasse a fazenda; (3) Paulo Honório fosse um literato de profissão (e, então, não me

\footnotetext{
${ }^{3}$ Cabe ressaltar que Lukács escreveu em 1967 um posfácio crítico de História e consciência de classe. Como não pretendo discutir o livro de Lukács, achei que seria demasiado retomar as idéias desse prefácio no corpo do texto. Entretanto, parece-me caber uma explicação a respeito da autocrítica de Lukács. Nesse posfácio, Lukács acusa a si mesmo de levantar "problemáticas éticas puramente idealistas". "A relação objetivamente social de alienação e todas as marcas subjetivas da alienação interior que são sua consequiência necessária só surgem quando as formas objetivadas assumem na sociedade funções que põem a essência do homem em oposição ao seu ser, que oprimem, deformam, etc., a essência do homem pelo ser social. Ora, em História e consciência de classe esta dualidade não era percebida." (p.364) Na seqüência, Lukács salienta que usou como sinônimos, em algumas passagens, termos que são concreta e conceitualmente diversos, no caso, reificação e alienação. Por fim, afirma que o mais importante de seu livro foi chamar a atenção para o aspecto importante da alienação na vida mercantilista, bem como para o aspecto de totalidade estrutural que constitui a produção do valor do capital e a reificação.
} 
furto à piada, a finura do livro seria mais verossímil?): se tudo isso fosse verdade, ao procurar "tirar o véu da reificação" o livro evocaria interpretações prontas. Na interpretação de São Bernardo, pouco está pronto: o leitor tem trabalho para reconstruir as elipses e mesmo para elaborar uma idéia precisa do enredo. O livro vigia as reificações de quem se pretende - com modos ligeiros - algoz da reificação e resiste - com silêncio em punho - ao empenho sempre renovado de fixar o sentido dos livros e da leitura.

Em todo o caso, Paulo Honório consegue construir a si mesmo como personagem porque se subjetiva, se isola e se afasta, criando anteparos para a objetividade da totalidade reificada. Ele se aliena do mundo comercial e constrói pela escrita de suas memórias uma recriação de sentido - espécie de alienação ética. Se antes da morte de Madalena o romance se guiava pelos passos da acumulação, depois, é a própria morte que faz Paulo Honório dimensionar o tempo e as atitudes - ecoando, inadvertidamente, numa passagem de Lukács, para mim pungente:

O que pode um ser humano, pergunta Lukács, ser para outro ser humano? [...] Na morte - na
morte de outrem - mostra-se talvez claramente, com uma intensidade superior à da força com
que os sonhos poderiam obscurecê-lo, o grande problema da existência dos homens na relação
de uns com os outros: o que um ser humano pode significar na vida de outro ser humano. [...]
A morte talvez seja apenas um símbolo do ficar sozinho. (LUKÁCS apud KONDER, 1980,
p.21)

Nesse Paulo Honório, é preciso ter em conta, o mundo cultural é alteridade que, com trabalho, se torna mediação para sua subjetividade. A "cultura", para milhões de brasileiros, tem sido forte alteridade, muitas vezes, alteridade bárbara, autoritária e subjugadora. A presença de Paulo Honório na literatura é fruto de trabalho - em que, ao se afirmar, Paulo Honório se nega. Em termos ficcionais, foi preciso que essa personagem chegasse a ser um burguês - burguês? - para depois escrever. A particularidade da sua trajetória remete à generalidade da história do romance (gênero), ligada à ascensão da burguesia, de um mercado cultural capitalista e da intensificação de pedaços de sentidos compartilhados de modo cada vez mais abrangente: a intensificação da uniformização dos sentidos pela recorrência de formas, a partir da perda de sentido comunitário.

O trabalho literário do livro, por assim dizer, faz cindir forma e conteúdo, mas não para sinalizar a cisão e sim para denunciar o valor positivo da coesão. Ironia sutil em que o leitor apreende um discurso a partir do absurdo, da frieza, da desumanização. Desamparado pela crueza da linguagem, o leitor pode encontrar sentido na própria crueza; impossibilitado, pela estrutura do livro, de ler a trajetória de Paulo Honório em chave romanesca precisará lançar a interpretação para o social. Isso não favorecerá a linguagem do social, reificada, mas 
exigirá um esforço de leitura entre o literário e o social: eis, ao que me parece, a grandeza do livro. Graciliano Ramos inscreve literatura e sociedade numa mesma formação discursiva, indiferenciando os dois "pólos", numa proposição de vanguarda. O par opositivo, com o qual costumamos construir teoricamente a literatura, precisará ser outro. O livro dialetiza com o modo de produção, está inscrito nele, mimetiza-o de modo que o pensamento se vê livre para atentar contra o dualismo que nos automatiza o senso, fundando, quem sabe, um senso de totalidade contraditória, na qual a reificação serve para denunciar-se a si mesma, pelo absurdo de sua dureza. Nesse caso, Adorno nos ajuda a ver que a arte pode produzir uma mimese da reificação e exige do pensamento, como já dito, que dialetize em negativo: a síntese (?) daquilo que está reificado com aquilo que está reificado é uma reificação à segunda potência. Tal movimento soará tão absurdo e corresponderá - como em Kafka - a tal ponto com o social que, a um só tempo, poderá ser lida como absoluta literatura, absoluta arte, no mesmo ponto em que seria absoluta sociedade, absoluta reificação, absoluta submissão.

O estranhamento por um homem dessa cepa escrever - e escrever tão bem - não é um estranhamento do mundo subjetivo, mas do mundo objetivo. Em termos subjetivos, nas proposições do livro para com ele mesmo, trata-se de algo possível (escrevo possível, o que não quer dizer obrigatório). O estranhamento, na recepção, entre o livro e seu escritor é um dos grandes efeitos da obra, mais do que seu defeito. Se a subjetividade de Paulo Honório não pudesse ser obra de arte a não ser quando mediada por um narrador, isso delimitaria bem de quem é o ponto-de-vista mais geral da literatura brasileira como um todo: então, a literatura se organizou, pouco a pouco, para tornar inverossímil boa parte das subjetividades? A literatura caminhou para que subjetividades como as de Paulo Honório só fossem possíveis como objetividades, como dados da natureza ou como instrumentos do narrador? Se é assim em relação às subjetividades como as de Paulo Honório, que dirá quanto ao Fabiano, sinhá Vitória, dona Margarida? Nesse caso, a reificação mais monstruosa que aparece no livro é propriamente aquela da subjetividade de Paulo Honório, expressa numa linguagem que, ao que dizem, não é a sua, uma linguagem que lhe é estranha e, por lhe ser estranha, permite que o narrador construa sua subjetividade. A divisão do trabalho, ao tornar a própria obra como um objeto e evidenciar que a subjetividade de Paulo Honório só pode aparecer como trabalho desse Paulo Honório no mundo, torna evidente também o importante papel que os narradores em terceira pessoa, muitas vezes, têm na literatura brasileira: o de objetificar as personagens de classes pobres, exploradas e excluídas, escamoteando, com raras exceções, a subjetividade - o trabalho - necessário para a construção desses "dados". Em uma palavra: calando, pela inverossimilhança, determinada posição de fala. 
É como se estivéssemos dizendo: bom, já que ao Fabiano é negada a linguagem, então vamos permitir que ele possua uma subjetividade. Diante de Paulo Honório, só nos resta ler como inverossímil o fato de ele construir uma linguagem. Objetivamente, Paulo Honório e Fabiano propõem uma questão fundamental, pois, esse tipo de clivagem entre individualidade e linguagem é muito parecida com aquela que entendia o escravo como um ser sem alma.

Em Paulo Honório era preciso uma forma em que a reificação do homem atingisse seu cerne: quer dizer, que o impedisse de se expressar. A divisão do trabalho seria o livro, em termos formais, que expressaria a reificação. Como Paulo Honório escreve ele mesmo, São Bernardo livro se diferencia abruptamente da São Bernardo propriedade: Paulo Honório assume sua linguagem, ainda que muitos leitores não a assumam. A linguagem distante da primeira parte do livro, linguagem morta, como no episódio em que sabemos do nascimento do filho, exprime a reificação contra ela própria - humanizando o enunciado no extremo de sua desumanização, mas transferindo a reconstrução do efeito para o leitor em conflito com os valores sociais e os valores literários. Na segunda parte do livro, consciente de sua desumanização, vendo sem reagir sua propriedade se perder, e lidando com a culpa e a morte, Paulo Honório expressa seu conflito e a linguagem condiz mais com a expressão, de modo que nem Paulo Honório nem a linguagem são os mesmos.

Mais do que um contraste, a primeira e a segunda parte do livro afirmam um contraponto, uma reverberação. O caráter autoritário do capitalista que se faz burguês (?) precisa lidar com a morte física e chocante que, em termos simbólicos, pode remeter à completa desintegração do saber sobre o mundo. Lá onde a ciência - a zootecnia correspondia como argumento de autoridade para a fala capitalista, a literatura constrói, negando-se, uma denúncia da extrema reificação no horizonte social brasileiro, reificação que limita a própria interpretação literária aos eixos da exploração do verossímil - como se o verossímil dependesse somente e tão somente do imediato, isto é, das coisas como elas são.

O sujeito que Paulo Honório é só pode se realizar como linguagem inverossímil quando ele é medido pela régua dos Fabianos - com os quais Paulo Honório se identifica, em delírio, no final do romance:

Penso no povoado onde seu Ribeiro morou, há meio século. (...) Imagino-me vivendo no tempo da monarquia, à sombra de seu Ribeiro. Não sei ler, não conheço iluminação elétrica nem telefone. Para me exprimir recorro a muita perífrase e muita gesticulação. (...) Podem rebentar centenas de revoluções. Não receberei notícias delas. Provavelmente sou um sujeito feliz. (RAMOS, 1995, p.188)

A personagem idealiza a vida pobre, da qual se separou e não consegue mais rememorar. A idealização da pobreza, no entanto, remetida ao entrecho do capítulo, é 
identificação com a pobreza, um esforço de alienação de si, que resulta, enfim, em alguns conhecimentos a respeito de si e de sua condição como totalidade humana frente à totalidade social.

Nesse caso, seria preciso discordar cordialmente de Lafetá (1995) (e talvez de muitos leitores) quando afirmam que o livro nos conta "a vitória da reificação". A vitória da reificação - espero ter demonstrado - não ocorre cabalmente no livro, ocorre na sociedade que o interpreta quando o interpreta como dado imutável, alheio às mudanças históricas e atitudes interpretativas.

\section{Referências}

ADORNO, Theodor W. Teoria estética. Lisboa: Ed. 70, 1988.

BAKHTIN, Mikhail Mikhailovich. O freudismo: um esboço crítico. São Paulo: Perspectiva, 2004.

CARDOSO, Fernando Henrique. Capitalismo e escravidão no Brasil meridional: o negro na sociedade escravocrata do Rio Grande do Sul. Rio de Janeiro: Paz e Terra, 1977.

CARDOSO, Sebastião Marques. Os caminhos da crítica literária brasileira. Sem data. Disponível em: http://antivalor.vilabol.uol.com.br/. Acessado em 20 jan 2008.

CARPEAUX, Otto Maria. Visão de Graciliano. In: RAMOS, Graciliano. São Bernardo. Rio de Janeiro/São Paulo: Record, 1995, p. 231-239.

ELIAS, Norbert. Envolvimento e alienação. Rio de Janeiro: Bertrand Brasil, 1998.

FERNANDES, Florestan. A revolução burguesa no Brasil: ensaio de interpretação sociológica. Rio de Janeiro: Zahar, 1981.

FLORENTINO, Manolo. Em costas negras: uma história do tráfico de escravos entre a África e o Rio de Janeiro (séculos XVIIIi e XIX). São Paulo: Companhia das Letras, 1997.

FLORENTINO, Manolo e FRAGOSO, João. O arcaísmo como projeto: mercado atlântico, sociedade agrária e elite mercantil em uma economia colonial tardia - Rio de Janeiro, c.1790 - c.1840. Rio de Janeiro: Civilização Brasileira, 2001.

FRAGOSO, João. Homens de grossa aventura: acumulação e hierarquia na praça mercantil do Rio de Janeiro (1790-1830). Rio de Janeiro: Civilização Brasileira, 1998.

GOLDMANN, Lucien. A reificação. In: GOLDMANN, Lucien. Dialética e cultura. Rio de Janeiro: Paz e Terra, 1979, p. 105-151 
JAMESON, Fredric. Em defesa de Lukács. In: JAMESON, Fredric. Marxismo e forma: teorias dialéticas da literatura no século XX. São Paulo: Hucitec, 1985, p. 127-160.

LAJOLO, Marisa e ZILBERMAN, Regina. A formação da leitura no Brasil. São Paulo: Ática, 1996.

LAFETÁ, João Luiz. O mundo à revelia. In: RAMOS, Graciliano. São Bernardo. Rio de Janeiro/São Paulo: Record, 1995, p. 192-217.

LUKÁCS, Georg. História e consciência de classe: estudos de dialética marxista. Porto: Publicações Escorpião, 1974.

LUKÁCS, Georg. Ensaios sobre literatura. Rio de Janeiro: Civilização Brasileira, 1968.

OLIVEIRA, Francisco. A economia da dependência imperfeita. Rio de Janeiro: Graal, 1977.

RAMOS, Graciliano. São Bernardo. Rio de Janeiro/São Paulo: Record, 1995.

SCHWARZ, Roberto. Ao vencedor as batatas: forma literária e processo social nos inícios do romance brasileiro. São Paulo: Duas Cidades, 1988.

SANTIAGO, Silviano. Uma literatura nos trópicos: ensaios sobre dependência cultural. Perspectiva: Secretaria da Cultura, Ciência e Tecnologia do Estado de São Paulo, 1978.

TELLES, Renata. Latino-americanismo e orientalismo: Roberto Schwarz, Silviano Santiago e Edward Said. 2004. Disponível em: http://antivalor.vilabol.uol.com.br/ e também disponível em http://www.uel.br/cch/pos/letras/terraroxa. Acesso em 20 jan 2008. 